\title{
Pengaruh Penerapan Aplikasi Electronic Filling (e-filling) Terhadap Kepatuhan Wajib Pajak Orang Pribadi Dalam Melaporkan Surat Pemberitahuan Tahunan (SPT Tahunan).
}

\author{
( Studi Kasus Atas Penyampaian Surat Pemberitahuan Tahunan Pada Dosen, Karyawan dan Mahasiswa \\ Di Universitas Islam Kadiri, Kediri )
}

\author{
Oleh : \\ Puji Rahayu \\ Universitas Islam Kadiri \\ Fakultas Ekonomi Jurusan Akuntansi \\ 2016
}

\begin{abstract}
ABSTRAKSI
Reformasi yang dilakukan oleh Kementerian Keuangan khususnya dibidang perpajakan dengan memberikan fasilitas pelayanan yang lebih efisien kepada wajib pajak dalam memenuhi kewajiban perpajakan melalui modernisasi aplikasi perpajakan yaitu pelaporan perpajakan dengan menggunakan sistem Electronic Filling (e-filling). Dengan penggunaan teknologi informasi dalam perpajakan diharapkan dapat meningkatkan kepatuhan wajib pajak khususnya wajib pajak orang pribadi dalam melaporkan surat pemberitahuan pajak tahunan agar lebih efektif. Tujuan yang hendak dicapai dengan dilakukan penelitian ini adalah untuk mengetahui "Pengaruh Penerapan Aplikasi Electronic Filling (e-filling) Terhadap Kepatuhan Wajib Pajak Orang Pribadi Dalam Melaporkan Surat Pemberitahuan Tahunan (SPT Tahunan)" studi kasus atas penyampaian surat pemberitahuan tahunan pada dosen, karyawan dan mahasiswa di universitas islam kadiri, kediri.

Jenis data yang digunakan dalam penelitian ini adalah data primer. Data primer yang digunakan dalam penelitian ini berupa lokasi penelitian, jumlah dosen, karyawan dan mahasiswa. Tehnik analisis data yang digunakan dalam penelitian ini adalah regresi linier sederhana dengan menganalisis kuesioner dan respondennya adalah wajib pajak orang pribadi yang melaporkan surat pemberitahuan tahunan.

Dari hasil penelitian disimpulkan bahwa electronic filling (e-filling) masih ada kelemahan kelemahan sehingga Kantor Pelayanan Pajak (KPP) perlu mengadakan sosialisasi lagi terhadap wajib pajak orang pribadi dan memberikan pelatihan khusus di lingkungan universitas islam kadiri, kediri sehingga wajib pajak orang pribadi lebih mudah dalam mengoperasikan aplikasi $e$-filling. Melalui aplikasi e-filling dapat meningkatkan kepatuhan wajib pajak orang pribadi dalam melaporkan surat pemberitahuan tahunan secara mudah, cepat, efektif dan efisien serta terjaga kerahasiaan data perpajakan.
\end{abstract}

\section{Kata Kunci : Electronic Filling, Kepatuhan Wajib Pajak.}




\section{PENDAHULUAN}

\section{Latar Belakang}

Pajak merupakan sumber penerimaan terbesar dalam Anggaran Penerimaan dan Belanja Negara (APBN). Pajak bersifat dinamika dan mengikuti perkembangan kehidupan negara serta masyarakatnya. Tuntutan akan peningkatan pendapatan negara juga tidak lepas dari reformasi terhadap kebijakan kementerian keuangan khususnya dibidang perpajakan dengan harapan pajak yang dipungut bisa maksimal.

Di era teknologi yang semakin maju khususnya di bidang elektronika, membawa dampak yang positif bagi kantor - kantor yang membutuhkan pelayanan cepat, tepat dan praktis. Hal ini menumbuhkan reformasi bagi Direktorat Jenderal Pajak yang dibawah naungan Kementerian Keuangan untuk melakukan pembaharuan - pembaharuan aplikasi perpajakan.

Salah satu bentuk pembaharuan yang dilakukan oleh Direktorat Jenderal Pajak yaitu melalui system Informationand Communication Technologies (ICT). Menurut Sutedjo, (2002) ICT atau teknologi informasi dapat diartikan sebagai suatu teknologi yang digunakan untuk mengolah data yang diperoleh dari setiap elemen sistem menjadi bentuk yang mudah dipahami dan merupakan pengetahuan yang relevan dalam berbagai cara untuk menghasilkan informasi yang berkualitas.

Modernisasi pajak terjadi pertama kali pada tahun 2005 saat dilaksanakannya jenis pelayanan kepada Wajib Pajak yang baru dalam rangka penyampaian surat pemberitahuan dan penyampaian perpanjangan surat pemberitahuan tahunan menggunakan electronic filling (e-filling).

E-Filling atau Electronic Filing System yaitu sistem pelaporan / penyampaian pajak dengan Surat Pemberitahuan (SPT) secara elektronik yang dilakukan melalui system on-line yang real time sehingga akan membantu 24 jam sehari dalam seminggu.
Dengan harapan wajib pajak dapat melaporkan kewajibannya secara efektif dan efisien.

Ketentuan Umum dan Tata Cara Perpajakan (UU KUP) no. 28 pasal 1 tahun 2007 disampaikan bahwa wajib pajak adalah orang pribadi atau badan, meliputi pembayaran pajak, pemotong pajak, dan pemungut pajak, yang mempunyai hak dan kewajiban perpajakan sesuai dengan ketentuan peraturan perundang-undangan.

Sedangkan surat Pemberitahuan (SPT) adalah Surat yang oleh wajib pajak digunakan untuk melaporkan perhitungan dan/atau pembayaran pajak, objek pajak, dan/atau harta dan kewajiban menurut ketentuan perundang-undangan perpajakan. Dalam KUP SPT dibagi menjadi dua yaitu SPT Masa dan SPT Tahunan.

Kepatuhan wajib pajak dapat dilihat dari cara memenuhi semua kewajiban perpajakannya. Kepatuhan perpajakan merupakan tindakan wajib pajak dalam pemenuhan kewajiban perpajakannya sesuai dengan ketentuan perundang-undangan dan peraturan pelaksanaan perpajakan yang berlaku dalam suatu Negara. Kepatuhan perpajakan dapat diidentifikasi melalui kepatuhan wajib pajak dalam mendaftarkan diri, kepatuhan untuk menyetorkan kembali SPT, kepatuhan dalam menghitung, dan membayar pajak terutang, kepatuhan dalam pelaporan dan pembayaran tunggakan.

Berdasarkan uraian diatas penulis tertarik untuk melakukan penelitian tentang penerapan aplikasi e-filling dengan judul "Pengaruh Penerapan Aplikasi Electronic Filling (e-filling) Terhadap Kepatuhan Wajib Pajak Orang Pribadi Dalam Melaporkan Surat Pemberitahuan Tahunan (SPT Tahunan)." (Studi Kasus Atas Penyampaian Surat Pemberitahuan Tahunan Pada Dosen, Karyawan dan Mahasiswa Di Universitas Islam Kadiri, Kediri ). 


\section{Perumusan Masalah}

Berdasarkan latar belakang di atas maka penulis dapat merumuskan permasalahan sebagai berikut : Bagaimana Pengaruh Penerapan Aplikasi Electronic Filling (e-filling) Terhadap Kepatuhan Wajib Pajak Orang Pribadi Dalam Melaporkan Surat Pemberitahuan Tahunan (SPT Tahunan).

\section{Batasan Penelitian}

Untuk menghindari supaya tidak terjadi perluasan pembahasan dan juga penelitian lebih terarah, maka penulis membatasi penelitian hanya pada pengaruh penerapan aplikasi electronic filling (e-filling) terhadap kepatuhan wajib pajak orang pribadi dalam melaporkan surat pemberitahuan tahunan (SPT tahunan). Data yang dianalisis peneliti yaitu penyampaian surat pemberitahuan tahunan masa pajak yang dilaporkan dosen, karyawan dan mahasiswa yang telah ber-NPWP pada tahun pajak 2010 sampai 2015.

\section{Tujuan Penelitian}

Sesuai dengan permasalahan yang diuraikan diatas, maka tujuan dari penelitian ini adalah untuk mengetahui pengaruh penerapan aplikasi electronic filling (e-filling) terhadap kepatuhan wajib pajak orang pribadi dalam melaporkan surat pemberitahuan tahunan (SPT tahunan).

\section{Manfaat Penelitian}

Dari hasil penelitian yang dilakukan diharapkan dapat memberi beberapa manfaat antara lain:

a. Manfaat Operasional.

Hasil penelitian ini dapat dijadikan sebagai bahan masukan dan pertimbangan bagi dosen, karyawan dan mahasiswa dalam menyampaikan SPT Tahunan.

b. Manfaat Akademik.

Sebagai dasar memperdalam teori yang telah diperoleh dan menerapkannya di lapangan serta sebagai kajian bagi penelitian berikutnya.

\section{Model Hipotesis}

Hipotesis merupakan jawaban sementara terhadap rumusan masalah penelitian (Sugiono, 2008). Berdasarkan gambar model konseptual diatas dapat diajukan model hipotesis sebagai berikut :

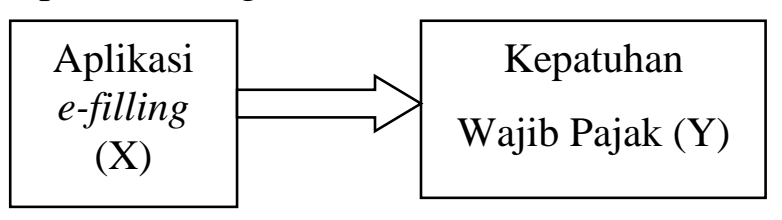

Gambar : 1 Model Hipotesa

Sumber : data diolah (2015)

Hipotesa : Diduga penerapan e-filling (X) berpengaruh terhadap kepatuhan wajib pajak (Y) dalam melaporkan SPT Tahunan.

\section{METODE PENELITIAN \\ Ruang Lingkup Penelitian}

Ruang lingkup dalam penelitian ini penulis mengkaji dalam bidang sistem aplikasi e-filling difokuskan pada masalah pengaruh penerapan aplikasi electronic filling (e-filling) terhadap kepatuhan wajib pajak orang pribadi dalam melaporkan surat pemberitahuan tahunan (SPT tahunan) pada dosen, karyawan dan mahasiswa Uniska yang telah terdaftar menjadi wajib pajak orang pribadi.

\section{Lokasi Penelitian}

Lokasi penelitian yang dijadikan obyek penelitian oleh penulis adalah Universitas Islam Kadiri yang terletak di jalan Sersan Suharmaji No. 38 Kel. Manisrenggo Kec. Kota kota Kediri, Jawa Timur. Alasan penulis melakukan penelitian karena sebagai berikut :

a. Sistem Aplikasi e-filling layak untuk dijadikan penelitian.

b. Dosen, karyawan dan mahasiswa dalam lingkungan uniska yang telah terdaftar menjadi wajib pajak orang pribadi bersifat terbuka dalam memberikan informasi. 


\section{Jenis Data dan Sumber Data}

\section{Jenis Data}

Jenis data yang akan dianalisis adalah sebagai berikut:

Jenis data yang digunakan dalam penelitian ini sebagai berikut :

a. Data Kuantitatif

Data kuantitatif yang dipakai dalam penelitian ini adalah jumlah dosen, karyawan dan mahasiswa uniska.

b. Data Kualitatif

Data kualitatif yang dipakai dalam penelitian ini adalah data tentang gambaran umum uniska, lokasi uniska, sistem aplikasi e-filling, surat pemberitahuan tahunan (SPT Tahunan) yang telah dilaporkan dan hasil kuesioner.

\section{Sumber Data}

Sumber data yang digunakan penulis dalam mengevaluasi untuk mendapatkan kesimpulan penelitian adalah data primer, yaitu berupa data tentang jumlah dosen, karyawan dan mahasiswa, gambaran umum uniska, lokasi uniska, sistem aplikasi e-filling, SPT Tahunan yang telah dilaporkan dan hasil kuesioner.

\section{Teknik Pengumpulan Data}

a. Wawancara

Wawancara dilakukan dengan dosen, karyawan, dan mahasiswa untuk memperoleh data tentang sistem aplikasi $e$-filling.

b. Dokumentasi

Dari dokumentasi diperoleh data tentang jumlah dosen, karyawan dan mahasiswa, gambaran umum UNISKA, lokasi uniska dan SPT Tahunan yang telah dilaporkan .

c. Kuisioner

Kuisioner ini dimaksudkan untuk memperoleh data tentang penerapan aplikasi $e$-filling terhadap kepatuhan wajib pajak orang pribadi dalam melaporkan surat pemberitahuan tahunan (SPT Tahunan).

\section{Identifikasi Variabel}

Dalam penelitian ini variabel yang diteliti terdiri dari dua macam, yaitu :
a. Aplikasi $e$-filling
b. Kepatuhan Wajib Pajak

\section{Definisi Operasional Variabel}

a. Aplikasi $e$-filling

Adalah Surat Pemberitahuan Masa atau Tahunan yang berbentuk formulir elektronik dalam media komputer, di mana penyampaiannya dilakukan secara elektronik dalam bentuk data digital yang ditransfer atau disampaikan ke Direktorat Jenderal Pajak melalui Perusahaan Penyedia Jasa Aplikasi atau Application Service Provider (ASP) yang telah ditunjuk oleh Direktur Jenderal Pajak dengan proses secara online. (Keputusan Direktur Jenderal Pajak Nomor: KEP88/PJ./2004 tanggal 14 Mei 2004 jo KEP05/PJ./2005 tanggal 12 Januari 2005)

b. Kepatuhan Wajib Pajak

Adalah suatu keadaan dimana wajib pajak memenuhi semua kewajiban perpajakan dan melaksanakan hak perpajakannya (Rahman, 2010).

\section{Idikator Variabel}

Variabel independen atau variabel bebas (X) adalah variabel yang mempengaruhi atau menjadi sebab timbulnya perubahan pada variabel terikat. Sedangkan variabel dependen atau variabel terikat (Y) adalah variabel yang dipengaruhi atau menjadi akibat karena adanya perubahan dari variabel bebas. Adapun indikator - indikator yang terkait dalam variabel - variabel ini adalah :

a. Indikator Aplikasi e-filling, sebagai berikut :

1. Kemudahan dalam mengoperasikan aplikasi $e$-filling .

2. Kemudahan dalam melaporkan SPT Tahunan menggunakan aplikasi e-filling.

3. Ketepatan dan kecepatan dalam melaporkan SPT Tahunan 
menggunakan aplikasi e-filling sehingga lebih efektif.

4. Efisiensi biaya, waktu dan tenaga dalam melaporkan SPT Tahunan dengan menggunakan aplikasi e-filling sehingga lebih ekonomis dan praktis.

b. Indikator Kepatuhan Wajib Pajak, sebagai berikut :

1. Kepatuhan untuk menyetorkan kembali SPT yaitu berupa tepat waktu dalam membayar pajak, dan banyaknya tempat pembayaran pajak yang dapat memudahkan dalam membayar pajak.

2. Kepatuhan dalam menghitung, memperhitungkan, dan membayar pajak terutang yaitu berupa melakukan perhitungan dengan benar, penerapan sanksi yang tegas, dan pemeriksaan pajak oleh petugas pajak.

3. Kepatuhan dalam Pelaporan dan mengetahui batas akhir pelaporan pajak.

4. Kepatuhan dalam pelaporan dan pembayaran tunggakan, yaitu berupa tunggakan pajak yang menambah beban pajak dan kesediaan wajib pajak dalam membayar tunggakan pajak.

\section{Metode Pengukuran Variabel}

Populasi dalam penelitian ini yaitu 100 orang responden diambil secara sampel acak dari dosen, karyawan dan mahasiswa uniska yang telah terdaftar menjadi wajib pajak orang pribadi. Untuk mempermudah peneliti menentukan responden dengan kriteria sebagai berikut : responden merupakan dosen, karyawan dan mahasiswa uniska yang telah ber-NPWP dan melaporkan SPT Tahunan masa pajak 2010 - 2015.

Skala pengukuran yang digunakan dalam mengklasifikasi variabel yang diukur supaya tidak terjadi kesalahan dalam menentukan analisis data adalah skala likert. Skala likert digunakan untuk mengukur sikap, pendapat dan persepsi seseorang atau sekelompok tentang kejadian atau gejala sosial. (Sugiyono, 2008).

\section{Teknik Analisis Data}

Metode analisis data yang dipergunakan untuk menjawab hipotesis adalah analisis deskripsi dan analisis regresi linier sederhana. Alasan penggunaan model regresi ini untuk mengetahui hubungan antara variabel independen yaitu aplikasi e-filling (X), terhadap variabel dependen yaitu kepatuhan wajib pajak (Y).

Persamaan model dari analisis regresi linier sebagai sebagai berikut:

$\mathrm{Y}=\mathrm{a}+\mathrm{bx}$

Keterangan :

Y : Kepatuhan wajib pajak

a : Konstanta dari persamaan regresi

$b_{\mathrm{X}}$ : Koefisien regresi dari variabel $\mathrm{X}$ (Aplikasi e-filling)

Adapun langkah-langkahnya sebagai berikut:

a. Analisis kuesioner yang telah diisi oleh 100 responden berkaitan dengan penerapan aplikasi $e$-filling terhadap kepatuhan wajib pajak orang pribadi dalam melaporkan surat pemberitahuan tahunan (SPT tahunan). Hasil jawaban kuesioner tersebut dibuatkan tabel ditribusi.

b. Menentukan skor jawaban responden dengan ketentuan skor yang telah ditetapkan

c. Menjumlah skor jawaban yang diperoleh dari tiap-tiap responden

d. Memasukkan skor tersebut ke dalam program SPSS versi 16.0.

\section{HASIL PENELITIAN DAN PEMBAHASAN}

Gambaran umum lokasi penelitian.

Universitas Islam Kadiri adalah salah satu universitas swasta yang ada di kediri dan merupakan unit Perguruan Tinggi yang pendirian serta pengelolaannya dilaksanakan oleh Yayasan Bina Cendikia Muslim 
Pancasila (YBCMP). Universitas Islam Kadiri didirikan pada tanggal 20 Juni 1983 oleh Yayasan Bina Cendikia Muslim Pancasila. Berdirinya Universitas Islam Kadiri ini didorong langsung oleh Kepala Daerah Tingkat II Kotamadya Kediri, dengan surat Rekomendasinya Nomor 421.4/574/441.16/83, menyusul kemudian dari Majelis Ulama Indonesia (MUI) dengan surat edaranya Nomor 05/X/MUI/1983, dan beberapa tokoh masyarakat lainnya di kota Kediri, yang akhirnya sampai tahun 2008 Universitas Islam Kadiri mempunyai 6 (enam) Fakultas, 10 Jurusan dan 12 Program Studi yaitu Fakultas Keguruan dan Ilmu Pendidikan (Pendidikan Bahasa dan Seni/ Pend.Bhs.Inggris, Pendidikan Luar Sekolah), Fakultas Pertanian (Agronomi/ Budi Daya Pertanian/ Agroteknologi, Peternaan/ Produksi Ternak, Agro Industri Pertanian/ Teknologi Industri Pertanian), Fakultas Hukum (Ilmu Hukum), Fakultas Ekonomi (Manajemen,Akuntansi), Fakultas Teknik (Elektro), Pasca Sarjana (Magister Manajemen, Magister Manajemen Agribisnis, Magister Ilmu Hukum).

\section{Uji Validitas dan Reliabilitas \\ Uji Validitas}

Dari hasil uji validitas dari variable bebas dan terikat dapat diketahui bahwa item dari masing-masing variabel memiliki nilai koefisiensi korelasi > 0,3 dengan nilai signifikansi $\leq 0,05$. Dengan demikian item dari masing-masing variabel bebas dan terikat dinyatakan valid.

\section{Uji Reliabilitas}

Dari hasil uji reliabilitas dari variabel bebas dan terikat dapat diketahui nilai koefisien reliabilitas adalah 0,706. Sesuai kriteria, nilai ini sudah lebih besar dari 0,60, maka hasil dari data kuesioner memiliki tingkat reliabilitas yang baik, dengan kata lain data tersebut dapat dipercaya.

\section{Analisis Deskriptif}

Hasil dari analisis deskriptif merupakan penyederhanaan data responden penelitian yang berbentuk identitas responden penelitian. Hasil analisis deskriptif dapat dilihat pada tabel berikut :

\begin{tabular}{|l|r|r|r|}
\multicolumn{4}{|c|}{ Tabel 1 } \\
\hline \multirow{2}{*}{ Keterangan } & \multicolumn{2}{|c|}{ Jenis Kelamin } & \multirow{2}{*}{ Total } \\
\cline { 2 - 3 } & \multicolumn{1}{|c|}{$\begin{array}{c}\text { Laki - } \\
\text { laki }\end{array}$} & $\begin{array}{c}\text { Perempu } \\
\text { an }\end{array}$ & \\
\hline Usia (Tahun) & & & \\
\hline$<30$ & 25 & 30 & 55 \\
\hline $30-40$ & 15 & 25 & 40 \\
\hline$>40$ & 4 & 1 & 5 \\
\hline Pendidikan & & & \\
Formal & & & \\
Terakhir & & & \\
\hline SD Sederajat & 2 & 0 & 2 \\
\hline SMP Sederajat & 3 & 0 & 3 \\
\hline SMA Sederajat & 15 & 20 & 35 \\
\hline D1-D3 & 5 & 8 & 13 \\
\hline S1 & 7 & 10 & 17 \\
\hline S2 & 10 & 15 & 25 \\
\hline S3 & 4 & 1 & 5 \\
\hline Sumber : Data & diolah (2015) & \\
\hline
\end{tabular}

\section{Analisis Regresi Linier Sederhana}

Dari hasil jawaban kuesioner yang telah diisi oleh responden dan telah diolah dengan bantuan SPSS Versi 16.0 maka hasil perhitungan analisis regresi linier sederhana pada penelitian tentang pengaruh penerapan aplikasi e-filling terhadap kepatuhan wajib pajak orang pribadi dalam melaporkan surat pemberitahuan tahunan (SPT tahunan), sebagai berikut :

\section{Persamaan Regresi}

Hasil analisis regresi linier berganda diperoleh persamaan regresi berikut: $\mathrm{Y}=3,925+1,058 \mathrm{X}$

Keterangan :

Y : Kepatuhan wajib pajak

$\mathrm{X}$ : Aplikasi e-filling 
Pada persamaan tersebut dapat dilihat variabel bebas pada penelitian ini berpengaruh positif terhadap variable terikat.

\section{Pengujian Hipotesis}

\section{Koefisien Determinan $\left(\mathbf{R}^{\mathbf{2}}\right)$}

Berdasarkan hasil uji koefisien determinasi besarnya $\mathrm{R}$ dalam penelitian ini adalah 0,895 yang menunjukkan bahwa terjadi hubungan yang positif antara persepsi aplikasi e-filling terhadap kepatuhan wajib pajak orang pribadi dalam melaporkan SPT Tahunan.

Nilai R square yang merupakan nilai $\mathrm{R}^{2}$ sebesar $0,802=80,2 \%$ memiliki arti bahwa variabel persepsi aplikasi e-filling mempengaruhi kepatuhan wajib pajak orang pribadi dalam melaporkan SPT Tahunan. Sisanya $19,8 \%$ berasal dari variabel lain.

\section{Pembahasan}

Berdasarkan hasil penelitian yang telah dilakukan dapat diketahui bahwa variabel bebas yaitu penerapan aplikasi e-filling mempengaruhi variabel terikat yaitu kepatuhan wajib pajak sebesar 80,2\% dengan indikator wajib pajak patuh tercermin dari kepatuhan untuk menyetorkan kembali SPT yaitu berupa tepat waktu dalam membayar pajak, dan mengetahui banyaknya tempat pembayaran pajak yang dapat memudahkan dalam membayar pajak, kepatuhan dalam menghitung, memperhitungkan, dan membayar pajak terutang yaitu berupa melakukan perhitungan dengan benar, penerapan sanksi yang tegas, dan pemeriksaan pajak oleh petugas pajak, kepatuhan dalam melaporkan dan mengetahui batas akhir pelaporan pajak, kepatuhan dalam melaporkan dan pembayaran tunggakan, yaitu berupa tunggakan pajak yang menambah beban pajak dan kesediaan wajib pajak dalam membayar tunggakan pajak serta mengetahui banyaknya tempat melaporkan pajak (baik secara manual/dropbox atau e-filling) yang dapat memudahkan dalam melaporkan pajak dan ada faktor lain sebesar $19,8 \%$ yang mempengaruhi variabel terikat diluar variabel yang diteliti. Berikut pembahasan tentang variabel bebas terhadap variabel terikat :

\section{Pengaruh Penerapan Aplikasi e-filling Terhadap Kepatuhan Wajib Pajak Orang Pribadi Dalam Melaporkan SPT Tahunan.}

Berdasarkan hasil pengujian $\mathrm{H} 1$ dan $\mathrm{H} 2$ dengan menggunakan uji $\mathrm{t}$ menunjukkan bahwa probabilitas $t_{\text {hitung }}$ penerapan aplikasi $e$-filling adalah sebesar 1,782 ( $\operatorname{sig} \mathrm{t}<0,05)$. Hasil pengujian ini menunjukan bahwa penerapan aplikasi e-filling berpengaruh secara parsial terhadap kepatuhan wajib pajak orang pribadi. Hasil penelitian ini menunjukan bahwa penerapan aplikasi $e$-filling meningkatkan kepatuhan wajib pajak orang pribadi dalam melaporkan SPT Tahunan.

Penerapan aplikasi $e$-filling dalam sistem perpajakan yang menganut self assesstment system di Indonesia menuntut kepada wajib pajak untuk melaksanakan kewajiban perpajakannya sendiri. Aplikasi e-filling merupakan system aplikasi komputer yang dibuat oleh Direktorat Jendral Pajak (DJP) yang ditujukan untuk wajib pajak dalam melaporkan SPT Tahunan. Pelaporan SPT Tahunan dengan menggunakan aplikasi e-filling dinilai lebih efisien dari pada menggunakan SPT manual, sehingga dengan menggunakan $e$-filling wajib pajak dapat dengan mudah melaksanakan kewajiban perpajakan. Keunggulan yang dimiliki oleh aplikasi e-filling memakai sistem computer dan internet sehingga wajib pajak dapat dengan baik mengorganisasikan data perpajakan secara sistematis, dan cepat seta terjaga kerahasiaan data pajak yang telah dilaporkan. Kelebihan lain dalam melaporkan SPT Tahunan menggunakan $e$ filling wajib pajak tidak perlu lagi mengantri di kantor pajak maupun tempat melaporkan SPT Tahunan lain (dropbox).

Hasil penelitian ini didukung oleh peneliti sebelumnya oleh Zuhdi (2015:6) dengan judul penelitian "Pengaruh Penerapan e-SPT Dan Pengetahuan Perpajakan Terhadap Kepatuhan Wajib Pajak" hasil penelitian 
menunjukan yaitu penerapan e-SPT berpengaruh terhadap kepatuhan wajib pajak secara parsial yang artinya, dengan meningkatnya penerapan e-SPT maka akan dapat mengkatkan kepatuhan wajib pajak dan didukung juga oleh Risky (2015:8) dengan judul penelitian "Analisis Faktor-Faktor Yang Mempengaruhi Intensitas Perilaku Dalam Penggunaan Sistem e-filling". Hasil penelitian uji t (parsial) menunjukan bahwa variabel persepsi kegunaan, persepsi kemudahan, persepsi kerumitan, persepsi keamanan dan kerahasiaan, dan persepsi kesiapan teknologi informasi wajib pajak tersebut bertanda positif dan signifikan terhadap intensitas perilaku penggunaan sistem $e$-filling $(\mathrm{Y})$.

\section{KESIMPULAN DAN SARAN Kesimpulan}

Dari hasil penelitian yang peneliti lakukan di universitas islam kadiri, serta berdasarkan hasil pembahasan maka dapat ditarik kesimpulan sebagai berikut :

a. Dari hasil uji t (parsial) menunjukkan bahwa variabel bebas atau variabel independen yaitu aplikasi e-filling tersebut bertanda positif dan signifikan terhadap variabel terikat atau variabel dependen yaitu kepatuhan wajib pajak (Y). Hasil tersebut menunjukan bahwa penerapan aplikasi $e$-filling meningkatkan kepatuhan wajib pajak orang pribadi dalam melaporkan SPT Tahunan.

b. Dari hasil uji koefisien determinasi besarnya $\mathrm{R}$ menunjukan bahwa terjadi hubungan yang positif antara persepsi aplikasi e-filling terhadap kepatuhan wajib pajak orang pribadi dalam melaporkan SPT Tahunan.

c. Hasil dari $\mathrm{R}$ square menunjukan bahwa variabel persepsi aplikasi e-filling mempengaruhi kepatuhan wajib pajak orang pribadi dalam melaporkan SPT Tahunan.

d. Kelebihan yang ditawarkan oleh aplikasi e-filling meliputi kemudahan dalam melaporkan SPT Tahunan sehingga lebih efektif, efisien, ekonomis dan praktis. e. Keunggulan lain yang dimiliki oleh aplikasi e-filling memakai sistem computer dan internet sehingga wajib pajak dapat mengorganisasikan data perpajakan secara sistematis, dan cepat serta terjaga kerahasiaannya. Selain itu wajib pajak tidak perlu lagi mengantri di kantor pajak maupun tempat melaporkan SPT Tahunan lain (dropbox).

f. Kepatuhan wajib pajak akan lebih meningkat dengan berbagai kemudahan dan kelebihan yang di miliki oleh aplikasi e-filling.

\section{Saran}

Disini penulis mencoba memberikan saran - saran dengan harapan dapat memberi manfaat bagi peneliti selanjutnya yang berkaitan dengan penerapan aplikasi e-filling terhadap kepatuhan wajib pajak orang pribadi dalam melaporkan SPT Tahunan. Saran-saran yang diberikan antara lain :

a. Sebaiknya diadakan sosialisasi tentang aplikasi e-filling oleh KPP setempat di lingkungan kampus universitas islam kadiri yang sifatnya terbuka untuk umum sehingga wajib pajak orang pribadi bisa lebih mudah mengoperasikannya. Selain itu, perlu di beri pengarahan tentang manfaat aplikasi e-filling untuk lingkungan sekitar, agar wajib pajak lebih patuh dalam melaksanakan kewajibannya.

b. Mengingat aplikasi e-filling sangat berpengaruh terhadap kepatuhan wajib pajak hal ini agar mendapat perhatian khusus oleh pihak DJP untuk terus melakukan inovasi. Sebaiknya, DJP melakukan penambahan untuk perusahaan penyedia jasa aplikasi / Application Service Provider (ASP) sehingga e-filling dapat digunakan wajib pajak secara merata.

c. Sebaiknya peraturan perpajakan mengenai tata cara pelaporan dan pengolahan surat pemberitahuan tahunan perlu dilakukan perbaikan semudah mungkin dan tidak rumit, sehingga wajib pajak mau 
menggunakan sistem e-filling dalam melaporkan SPT Tahunan.

d. Sebaiknya untuk penelitian berikutnya peneliti dapat mengembangkan variabel penelitian agar dapat mengetahui peningkatan kepatuhan wajib pajak orang pribadi dalam melaporkan SPT Tahunan.

e. Sebaiknya untuk penelitian selanjutnya dapat memperluas populasi, sampel dan lokasi penelitian, karena dalam lingkungan universitas islam kadiri yang memiliki NPWP dan melaporkan SPT tahunan terbatas.

\section{DAFTAR PUSTAKA}

Dijen. (2014), Informasi E-Filling Melalui Penyedia Jasa Aplikasi Atau Aplication Service Provider (ASP). Diakses pada $07 \quad$ Februari 2016 dari http://www.pajak.go.id

Efferin, Sujoko. Stevanus Hadi Darmaji dan Yuliawati Tan (2004), Metode Penelitian Untuk Akuntansi, Malang : Bayumedia Publising.

Mardiasmo, (2009). Perpajakan. Edisi Revisi, Yogyakarta : Andi Offset.

Muljono, Djoko dan Baruni Wicaksono.(2009). Akuntansi Pajak Lanjutan. Yogyakarta: Andi Offset.

Purwono, Herry. (2010). Dasar-Dasar Perpajakan dan Akuntansi Pajak. Yogyakarta : Erlangga.

Rahman, Abdul. (2010), Panduan Pelaksanaa Administrasi Perpajakan. Bandung: Penerbit Nuansa.

Republik Indonesia, Undang-Undang Nomor 28 Tahun 2007 tentang Perubahan Ketiga atas Undang-Undang Nomor 6 Tahun 1983 tentang Ketentuan Umum dan Tata Cara Perpajakkan.

Resmi, Siti. (2014). Perpajakan Teori dan Kasus. Jakarta : Salemba Empat.

Risky, Dianita. (2015), Analisis FaktorFaktor Yang Mempengaruhi Intensitas Perilaku Dalam Penggunaan Sistem EFilling. Jurnal Administrasi Bisnis Perpajakan (JAB) Vol. 6 No. 12015
Suandy, Erly (2011). Perencanaan Pajak, Edisi Keempat, Jakarta : Salemba Empat.

Sugiyono. (2008). Metode Penelitian Kuantitatif, Kualitatif, dan $R \& D$. Bandung: Alfabeta. 2011. Metode Penelitian Kuantitatif, Kualitatif, dan $R \& D$. Bandung: Alfabeta.

Supramono dan Theresia Woro Damayanti. (2010). Perpajakan Indonesia Mekanisme dan Perhitungan, Yogyakarta : Andi Offset.

Sutedjo, Budi. 2002. Pengantar Teknologi Informasi Internet. Yogyakarta: Andi Offset.

Waluyo (2013), Perpajakan Indonesia, Edisi Kesebelas, Jakarta : Salemba Empat.

Zuhdi, Firdaus Aprian. 2015. Pengaruh Penerapan E-Spt Dan Pengetahuan Perpajakan Terhadap Kepatuhan Wajib Pajak (Studi Pada Pengusaha Kena Pajak yang terdaftar di KPP Pratama Singosari). Jurnal Perpajakan (JEJAK) Vol. 7 No. 1. 2015 